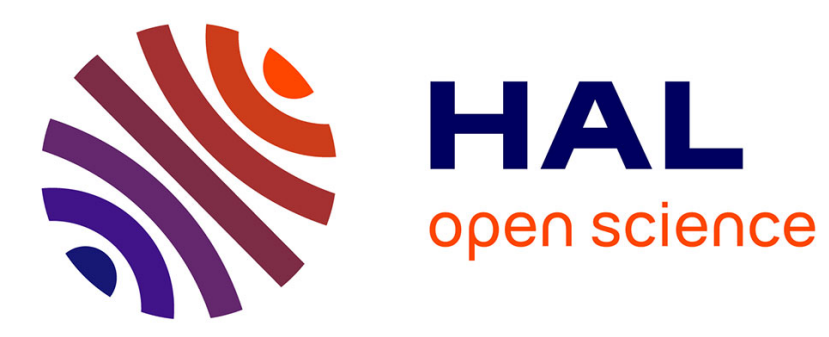

\title{
Persistence and biodegradation of kerosene in high-arctic intertidal sediment
}

Stian Røberg, Svein Kristian Stormo, Bjarne Landfald

\section{To cite this version:}

Stian Røberg, Svein Kristian Stormo, Bjarne Landfald. Persistence and biodegradation of kerosene in high-arctic intertidal sediment. Marine Environmental Research, 2007, 64 (4), pp.417. 10.1016/j.marenvres.2007.03.003 . hal-00562974

\section{HAL Id: hal-00562974 https://hal.science/hal-00562974}

Submitted on 4 Feb 2011

HAL is a multi-disciplinary open access archive for the deposit and dissemination of scientific research documents, whether they are published or not. The documents may come from teaching and research institutions in France or abroad, or from public or private research centers.
L'archive ouverte pluridisciplinaire HAL, est destinée au dépôt et à la diffusion de documents scientifiques de niveau recherche, publiés ou non, émanant des établissements d'enseignement et de recherche français ou étrangers, des laboratoires publics ou privés. 


\section{Accepted Manuscript}

Persistence and biodegradation of kerosene in high-arctic intertidal sediment

Stian Røberg, Svein Kristian Stormo, Bjarne Landfald

PII:

S0141-1136(07)00044-X

DOI:

10.1016/j.marenvres.2007.03.003

Reference:

MERE 3111

To appear in:

Marine Environmental Research

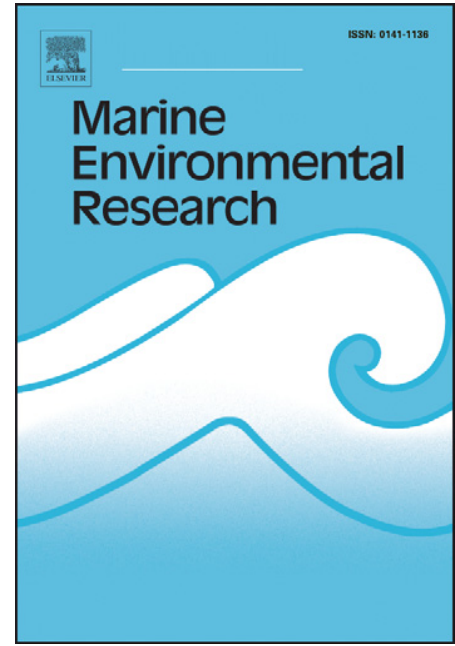

Received Date:

9 January 2007

Revised Date:

2 March 2007

Please cite this article as: Røberg, S., Stormo, S.K., Landfald, B., Persistence and biodegradation of kerosene in high-arctic intertidal sediment, Marine Environmental Research (2007), doi: 10.1016/j.marenvres.2007.03.003

This is a PDF file of an unedited manuscript that has been accepted for publication. As a service to our customers we are providing this early version of the manuscript. The manuscript will undergo copyediting, typesetting, and review of the resulting proof before it is published in its final form. Please note that during the production process errors may be discovered which could affect the content, and all legal disclaimers that apply to the journal pertain. 


\section{Persistence and biodegradation of kerosene in high-arctic} intertidal sediment

Stian Røberg, Svein Kristian Stormo, Bjarne Landfald*

The Norwegian College of Fishery Science, University of Troms $\varnothing$, NO-9037 Troms $\varnothing$, Norway

*corresponding author;

e-mail bjarne.landfald@nfh.uit.no,

tel. +4777644415

fax: +4777646020 


\section{Abstract}

A kerosene type hydrocarbon fraction (equivalent to $7 \mathrm{~L} \mathrm{~m}^{-2}$ ) was added to enclosures in the surface layer of high-arc tic intertidal beach sediment. The experimental spill was repeated in two consecutive years in the period July-September. The rate and extent of hydrocarbon removal and the accompanying bacterial response were monitored for 79 days (2002) and 78 days (2003). The bulk of added kerosene, i.e. 94 to 98 percent, was lost from the upper $5 \mathrm{~cm}$ layer by putatively abiotic processes within 2 days and a residual fraction in the range 0.6 to $1.2 \mathrm{mg}$ per $\mathrm{g}$ dry sediment was stably retained. Concomitant addition of oleophilic fertilizer led to higher initial retention, as $24 \%$ of the kerosene remained after 2 days in the presence of a modified, cold-climate adapted version of the well-known Inipol EAP 22 bioremediation agent. In these enclosures, which showed an increase in hydrocarbon-degrader counts from $6.5 \times 10^{3}$ to $4.1 \times 10^{7}$ per $\mathrm{g}$ dry sediment within 8 days, a 17\% contribution by biodegradation to subsequent hydrocarbon removal was estimated. Stimulation in hydrocarbon-degrader counts in fertilizer-alone control enclosures was indistinguishable from the stimulation observed with both kerosene and fertilizer present, suggesting that the dynamics in numbers of hydrocarbon-degrading bacteria was primarily impacted by the bioremediation agent.

\section{Keywords}

hydrocarbons, kerosene, bioremediation, intertidal zone, Arctic, Svalbard 


\section{Introduction}

The risk of accidental oil spills in the polar regions increases with the extent of human activities. The potentially most devastating incidents are obviously related to production and transport of crude oil, but the hazards of contamination from fuel oils are also increased in connection with activities such as tourist cruises, fisheries and research.

In the year-round low temperatures of the Arctic and the Antarctica, evaporation of even relatively light hydrocarbon fractions is low (Fingas, 2004), while viscosity is increased compared with temperate and warm regions (Jarsjö et al., 1997). Thus, the residence time of e.g. stranded spills must be expected to increase. This effect is further enhanced by the fact that the physicochemical processes of oil removal from the shorelines are largely discontinued for major parts of the year, when the beaches and adjacent waters are frozen and ice-covered.

Hydrocarbon-degrading bacteria have been shown to be ubiquitous members of the indigenous bacterial community in soil and aquatic environments, including permanently cold regions [reviews by Atlas (1981), Leahy and Colwell (1990), Margesin and Schinner (1999)]. Generally, these organisms constitute a small subset of the total community in pristine environments, but their relative numbers tend to increase by orders of magnitude in hydrocarbon-exposed areas. This response has been shown to be rapid, also at low temperatures (Delille et al., 1998; Margesin and Schinner, 1999). In natural soil and aquatic environments, the hydrocarbon-induced bacterial proliferation is generally restricted by too low inherent bioavailability of the macro-nutrients nitrogen and phosphorous. Growth stimulation by $\mathrm{N}$ and $\mathrm{P}$ supplementation is well documented frequently accompanied by increases in hydrocarbon biodegradation rates (Atlas and Bartha, 1972; Gibbs, 1975; Braddock et al., 1997; Xia et al., 2006). 
Studies on the use of fertilizers to stimulate bioremediation in intertidal zone systems include laboratory simulations (Swannell et al., 1995; Santas and Santas, 2000; Bachoon et al., 2001; Oh et al., 2001; Röling et al., 2002; Xu and Obbard, 2003), smallscale and pilot-scale on-site experiments (Venosa et al., 1997; Oudot et al., 1998; Swannell et al., 2000; Choi et al., 2002; Delille et al., 2002; Prince et al., 2003; Pelletier et al., 2004) and evaluations of countermeasures after real spill events (Bragg et al., 1994; Swannell et al., 1999; Maki et al., 2003). The intertidal zone poses particular problems of maintaining sufficiently high levels of added macronutrients. Specialized slow-release inorganic or oleophilic organic fertilizers, as well as repeated addition of conventional agricultural fertilizers, have been employed as bioremediation strategies. As comprehensively reviewed (Swannell et al., 1996; Lee, 2000; Zhu et al., 2004), nutrient additions seem to accelerate immediate biodegradation rates, but the effect on the overall long-term extent of removal has been more contradictory. The physical nature of the beach substrate, aeration, emulsion formation by wave action (Santas and Santas, 2000) and environmental temperature are among the factors that have been reported to interact with nutrient availability.

A dedicated oil bioremediation agent, like the Inipol EAP 22, which was used extensively during e.g. the Exxon Valdez cleanup (Bragg et al., 1994), combine surfactant properties to counter formation of water-in-oil emulsions, organic $\mathrm{N}$ and $\mathrm{P}$ sources and a hydrophobic carbon source (oleic acid) to boost bacterial growth (Ladousse and Tramier, 1991). However, the impact of this extra C-source addition on the biodegradation of the oil contamination itself has been questioned. The bacteria, even if carrying hydrocarbon-degrading capacity, complete the consumption of the alternative $\mathrm{C}$ sources before they attack the hydrocarbons. This has been demonstrated in pure culture 
of Marinobacter hydrocarbonoclasticus (Rivet et al., 1993) and with natural assemblages of intertidal bacteria (Swannell et al., 1995).

The present study addresses the rate and extent of surface layer removal of a relatively light (kerosene type) hydrocarbon contamination contained on a high-arctic intertidal beach location. Particular emphasis is on the swiftness and extent of the growth response by the inherent bacterial community and its capacity to biodegrade the residual contamination with or without amendment with an oleophilic fertilizer/ bioremediation agent.

\section{Materials and methods}

\subsection{Field site and sediment characteristics}

The field trials were carried out in the periods July-September of 2002 and 2003 at Kapp Wijk in the northern arms of the Isfjorden fjord system on Svalbard (N 78³6.5’, E $\left.015^{\circ} 10^{\prime}\right)$. A flat moraine peninsula, with an inlet well protected from high seas, is situated approximately $45 \mathrm{~km}$ from the nearest settlement (Longyearbyen) and has generally experienced little impact by human activities, except for occasional boat traffic in the surrounding waters. The grain size distribution in the upper $5 \mathrm{~cm}$ of the intertidal beach sediment was determined by serial dry sieving and classification according to the Udden-Wentworth scheme (Table 1). Sediment density was $1.77 \mathrm{~g} \mathrm{~cm}^{-3}$ and water content at low tide was in the range 9.7-17.8\%, depending on the interval between water retraction and sampling.

\subsection{Experimental setup}

The experimental periods lasted from 9 July to 26 September in 2002 (79 days) and from 7 July to 23 September in 2003 (78 days). Twelve $30 \mathrm{~cm}$ (i.d.) x $100 \mathrm{~cm}$ PVC tubes were 
placed vertically in the intertidal zone and covered and lidded with reflective $\mathrm{Al}$ foil to prevent from solar heating. They were dug $40 \mathrm{~cm}$ into the sediment and refilled to the same level as the surroundings. The tidal water percolated vertically through the enclosure sediment with just a few minutes delay relative to the surrounding sea surface oscillations. The tubes' positioning relative to the sea level was such that the orifice was not overflowed at maximum spring tides, while the sediment surface was still submerged at neap tides (Fig. 1). The enclosures were separated by $2 \mathrm{~m}$ and organized into 3 groups of 4 treatments each. After being allowed to settle for 3 days, triplicate enclosures were subjected to the following treatments: (1) no additions (control); (2) addition of $400 \mathrm{~g}$ (corresponding to $570 \mathrm{mg} \mathrm{cm}^{-2}$ ) of a $190-250^{\circ} \mathrm{C} \mathrm{bp} \mathrm{kerosene}(<0.3 \%$ aromatics) supplemented with heavier alkanes [3.5\% hexadecane (2003 only), 1.7\% heptadecane, $2.2 \%$ octadecane $1.1 \%$ nonadecane, $1.1 \%$ eicosane and $1.7 \%$ pristane $(2,6,10,14-$ tetramethylpentadecane) by weight]. All hydrocarbons were purum grade Fluka products; (3) Addition of $50 \mathrm{ml}$ of the oleophilic fertilizer/bioremediation agents Inipol EAP 22 (2002) or Inipol+ (2003), produced by CECA SA (France); (4) concomitant addition of $400 \mathrm{~g}$ of the kerosene mixture and $50 \mathrm{ml}$ Inipol (10 vol\% of hydrocarbons). In the 2003 experiment, addition of $50 \mathrm{ml} \mathrm{Inipol}^{+}$was repeated after 43 days. To assure an even distribution in the enclosure surfaces, the additions were done at ebb tide, but while the sediments were still submerged. The upper $5 \mathrm{~cm}$ layer was assumed to maintain a stable oxic atmosphere due its coarseness combined with the twice-a-day replenishments by fresh air and seawater through the tidal oscillations.

\subsection{Sampling}

Temperature was measured in the surface sediment inside and immediately outside three randomly chosen enclosures at low tide every sampling date. Duplicate core sediment 
samples were collected from each enclosure by pressing $50 \mathrm{ml}$ sterile plastic tubes $5 \mathrm{~cm}$ into the surface layer. The samples were subsequently transported on ice to a laboratory facility within 4 hours. The material for microbiological analyses was processed immediately, while the remainder was frozen at $-20^{\circ} \mathrm{C}$.

\subsection{Hydrocarbon analyses}

Two grams of thawed sediment were suspended in $5 \mathrm{ml}$ dichloromethane with $500 \mu \mathrm{g} 1$ hexadecene added as an internal standard. The suspension was vortexed twice for $15 \mathrm{~s}$ with a $5 \mathrm{~min}$ interval. After $30 \mathrm{~min}$ rest, $3 \mathrm{ml}$ of the clear supernatant were transferred to glass screw-cap tubes and stored at $5^{\circ} \mathrm{C}$. Samples were injected splitlessly by an A200S autosampler (Fisons Inst ruments, Altrincham, UK) onto a CP-Sil-8 CB column (25 x $0.25 \mathrm{~mm}$ i.d., Chrompack International, The Netherlands) installed in a Fisons 8060 Gas Chromotograph connected to a Fisons VG Platform II mass spectrometer. The column temperature was maintained at $50^{\circ} \mathrm{C}$ for $3 \mathrm{~min}$, then increased by $8^{\circ} \mathrm{C} \mathrm{min}-1$ to $130^{\circ} \mathrm{C}$ and $1^{\circ} \mathrm{C} \min ^{-1}$ to $140^{\circ} \mathrm{C}$. Thereafter, the column temperature was ramped to $280^{\circ} \mathrm{C}\left(15^{\circ} \mathrm{C}\right.$ $\min ^{-1}$ ) and held there for $5 \mathrm{~min}$. The injector temperature was $230^{\circ} \mathrm{C}$, the detector interface temperature $250^{\circ} \mathrm{C}$, the ion source temperature $180^{\circ} \mathrm{C}$, and the ionizing voltage $70 \mathrm{eV}$. Qualitative analyses were performed by scanning from 30 to 400 atomic mass units at a scan rate of $0.9 \mathrm{~s} / \mathrm{scan}$. Alternatively, identical GC temperature conditions were programmed on an Agilent 6890N gas chromatograph (Agilent Technologies, Palo Alto, USA) equipped with a similar column (VF-5ms, 30 x 0.25 mm i.d., Varian, Palo Alto, USA) and a flame ionization detector. Individual alkanes were quantitated from MS data by the areas from the total ion current or from flame ionization detector areas.

\subsection{Microbiological methods}


Cell suspensions in phosphate-buffered $2 \% \mathrm{NaCl}$ (PBS) were obtained according to Anderson et al. (2001) and 10-fold dilution series in PBS were used for viable cell enumerations. Numbers of viable hydrocarbon degraders (DC) were estimated by a modified most probable number (MPN) procedure (Brown and Braddock, 1990). Aliquots of $20 \mu \mathrm{l}$ were added into 7 separate dilution series in 96-microwell plates (NUNC A/S, Denmark). The wells were pre-filled with $180 \mu 11.5 \% \mathrm{NaCl}$-supplemented Bushnell-Haas mineral medium (Difco) and $5 \mu 1$ filter-sterilised kerosene mixture. After incubation in the dark at $6{ }^{\circ} \mathrm{C}$ for 3 months (Delille and Delille 2000), each well was inspected for dispersion of the kerosene (“Sheen Screen”) and subsquently added $50 \mu 1$ filter-sterilized $3 \mathrm{mg} \mathrm{ml}^{-1}$ solution of the respiration indicator INT (2-(4-iodophenyl)-3(4 nitrophenyl)-5-phenyltetrazolium chloride; Sigma-Aldrich) (Haines et al., 1996). After over-night incubation in the dark at $6^{\circ} \mathrm{C}$, red and pink wells were counte $\mathrm{d}$ as positive for growth. A maximum-likelihood estimation of microbial numbers based on 7-fold dilution series was developed for the Microsoft Exce $^{\circledR}$ for Windows spreadsheet program. Additionally, DC were estimated from colony counts of the appropriate dilutions on Petri dishes with solidified Bushnell-Haas medium after incubation at $6^{\circ} \mathrm{C}$ in a saturated kerosene atmosphere (Dandie et al., 2001).

For heterotrophic-count estimates (HC), dilution series were plated on Petri dishes with a half-strength Marine broth/peptone medium $\left(10 \mathrm{~g} \mathrm{~L}^{-1}\right.$ Marine broth 2216 (Difco), $5 \mathrm{~g} \mathrm{~L}^{-1}$ Bacto-peptone (Difco) $15 \mathrm{~g} \mathrm{~L}^{-1} \mathrm{NaCl}, 15 \mathrm{~g} \mathrm{~L}^{-1}$ agar (Difco). Plates were incubated for 3 weeks at $6^{\circ} \mathrm{C}$.

Suspended cells for epifluorescent microscopy total counts (TC) were subjected to short-term fixation in $4 \%$ paraformalde hyde with subsequent freeze storage in $50 \%$ ethanol according to the procedure of Pernthaler et al. (2001). The fixated cells were diluted 100-fold in ultrapure water, filtered through Whatman Anodisc 25 filters $(0.2 \mu \mathrm{m}$ 
pore size) and stained with SYBR Gold ${ }^{\circledR}$ (Sigma-Aldrich, USA) according to Noble and Fuhrman (1998), except that stained filters were dried overnight at $40^{\circ} \mathrm{C}$ prior to mounting. A total of 500-1000 bacteria-sized cells per filter were counted in a fluorescent microscope (Leitz DMRBE).

\subsection{Nitrogen, phosphorous and carbon content}

Sediment samples $(25 \mathrm{~g})$ were dried for $24 \mathrm{~h}$ at $40^{\circ} \mathrm{C}$, passed through a $2 \mathrm{~mm}$ mesh sieve and milled. Ten mg material was wrapped in tin cups and analysed for total $\mathrm{C}$ and $\mathrm{N}$ using a Perkin Elmer $2400 \mathrm{CHN}$ Element Analyzer (carrier gases $\mathrm{Ar}, \mathrm{O}_{2}$ and $\mathrm{He}$ ). Samples were heated to $640^{\circ} \mathrm{C}$ and $926^{\circ} \mathrm{C}$.

Inorganic and organic phosphate were extracted (Aspila et al. , 1976) and quantified by the colorimetric method of Murphy and Riley (1962).

\section{Results}

\subsection{Temperature and nutrients}

The surface sediment temperatures within the enclosures, as recorded at the sampling dates (Fig. 2), showed the same basic developments both years, i.e. fluctuations in the range 6 to $13^{\circ} \mathrm{C}$ in the period from start to mid-August, thereafter decreasing temperatures until freezing conditions emerged towards the end of the experiments. The reflective $\mathrm{Al}$ foil cover kept the insides of the enclosures slightly on the cold side of the naturally exposed beach throughout the summer periods. The differences were in the range 0.5 to 1 degree on cloudy days and 2 to 3 degrees in sunshine (data not shown).

The 7.4 weight\% urea-N in the Inipol bioremediation agent (Swannell et al., 1996) added $5.2 \mathrm{mg} \mathrm{cm}^{-2}$ of nitrogen to the fertilized enclosures. This quantity closely equalled the cumulative amount of total inherent $\mathrm{N}$ per $\mathrm{cm}^{2}$ in the upper $5 \mathrm{~cm}$ of the sediment, as 
determined from the un-fertilized enclosures of the 2003 experiment $(0.60 \pm 0.07 \mathrm{mg}$ per $\mathrm{g}$ dry sediment). However, no trend towards increased $\mathrm{N}$ levels in fertilized enclosures was detectable at first samplings 2-5 days after fertilizer addition or later throughout the experimental period.

The added $0.5 \mathrm{mg}$ organic $\mathrm{P} \mathrm{cm}-2(0.7 \%$ by weight as tri(laureth-4)-phosphate in the Inipol agent; Swannell et al. (1996) was a negligible contribution to total P of this exceptionally phosphorite-rich (Krajewski, 1992) sediment $(23 \pm 3 \mathrm{mg}$ per g dry sediment). It was equivalent to about one-third of the inherent organic $\mathrm{P}$ of the upper 5 $\mathrm{cm}$ layer (average $0.16 \mathrm{mg}$ per g dry sediment). Consequently, no significant differences in total or organic phosphate content were observed between treatments.

\subsection{Hydrocarbons reduction}

The bulk of added hydrocarbons were lost from the surface layer within the first few days. This was most evident in enclosures without accompanying fertilizer. In the 2002 experiment, about $98 \%$ of the initial kerosene load of $570 \mathrm{mg}$ per $\mathrm{cm}^{2}$ was lost from the upper $5 \mathrm{~cm}$ of sediment after 2 days, while the corresponding figure for 2003 was $94 \%$. Thereafter, the hydrocarbon reduction levelled out and residual concentrations stabilized at about $0.6 \mathrm{mg}$ per gdry sediment (2002) and $1.2 \mathrm{mg}$ per g (2003) (Fig. 3). With concomitant addition of the Inipol bioremediation agent, a higher fraction of the kerosene was retained in the upper layer. This was particularly evident in the 2003 experiment, when $24 \%$ of the initial load (i.e. $15.0 \mathrm{mg}$ per g dry sediment) was retained at day 2 . In 2002 the figure was $4.1 \%$. The subsequent removal rates in the fertilized enclosures were, however, higher, resulting in a merging of the retention curves after about a month (2002) or at the time of the termination of the experiment (2003). 
As the present kerosene product, on the whole, contained no biodegradationrecalcitrant components, equal quantities of pristane and heptadecane were included to monitor their ratio change as indicator of biodegradation. None of the kerosenesupplemented enclosures showed reduced ratio in 2002, nor did the un-fertilized enclosures in 2003 (Fig. 4). Rather, the straight-chain alkane tended to be retained in the sediment to a higher degree than its highly branched counterpart. This development seemed caused by physiochemical differences, as comparison of the fate of $n$-alkanes of various chain lengths confirmed a strict dependence on molecular size (Fig. 5). The $C_{17}$ and heavier n-alkanes disappeared more slowly than pristane, while the $\mathrm{C}_{16}$ and shorter molecules showed the opposite pattern. Thus the division point between molecules showing higher and lower retention than pristane did not coincide with heptadecane, but rather was situated in-between $\mathrm{C}_{16}$ and $\mathrm{C}_{17}$.

For Inipol-supplemented kerosene enclosures in the 2003 experiment, the $\mathrm{n}^{-} \mathrm{C}_{17}$ I pristane ratio decreased throughout the experimental period. An abrupt drop by $20 \%$ within the first 5 days (which was also observed in the 2002 experiment) was followed by a steady decline to a final ratio of 0.51 (Fig. 4). By disregarding the immediate reduction, which was plausibly abiotic by nature, a biodegradative contribution to overall $\mathrm{n}-\mathrm{C}_{17}$ loss from the upper layer could be estimated at $17 \%$ in the period of day 5 to the termination of the experiment at day 78 . This is a minimum estimate, as some accompanying microbial consumption of the pristane may be anticipated.

\subsection{Microbial enumerations}

The confinement of beach sediment in experimental enclosures seemed, by itself, to have little influence on cell numbers. Total epifluorescent counts (TC), which were in the ranges 3.4 to $6.6 \times 10^{7}$ per g dry sediment in 2002 and 1.2 to $2.8 \times 10^{7}$ per g in 2003, as 
well as viable heterotrophic (HC) and hydrocarbon-degrader counts (DC), all showed pronounced stability in the control tubes throughout the experimental periods (Fig. 6). Most-probable -number (MPN) estimates and colony-forming units on solid alkanesmineral salts media (data not shown) both gave estimates of DC in the range $0.01-0.03 \%$ of total cells, while the HC figures, on the whole, were 10-fold higher than DC. Based on colony morphologies and microscopic cell-size estimates, this hydrocarbon-degrading viable flora was exclusively of bacterial origin.

Addition of the kerosene mixture led to a marked increase in DC in the surface 5 $\mathrm{cm}$ layer within the first 2 weeks. For the rest of the experimental periods, the alkane degraders constituted a major part of viable cells, however still a minor fraction of the total counts. At most samplings, the HC and DC figures were two orders of magnitude below TC. The TC development further manifested the rather insignificant growthstimulatory effect of hydrocarbons alone, as no increase relative to the controls was traceable.

In the first-year experiment, the lack of growth stimulation was evident even when 10 vol\% of the Inipol EAP 22 agent was added concomitantly with the kerosene. However in 2003, the fertilizer-supplemented tubes showed a more notable development. Both the HC and DC figures exceeded $10^{7}$ per g dry sediment within a week, making viable cells a substantial fraction of the total microbial load. The growth-stimulatory effect was also reflected in a 3-fold increase in total counts. On the other hand, the stimulation was distinctly transient. By the next viable-count sampling 5 weeks later, the DC was down by two orders of magnitude. Following a second fertilizer addition, the high load of viable cells recurred. A six-fold increase in TC, peaking at $1.3 \times 10^{8}$ per $\mathrm{g}$ dry sediment within 6 days, seemed exclusively due to the growth of readily cultivable variants - including a substantial fraction with capacity for alkanes catabolism. 
The boost of alkane degraders in the presence of the Inipol agent in 2003 was evidently effected by components of this product. When added without accompanying hydrocarbons, the oleophilic fertilizer caused developments in microbial numbers alkane degraders included - which basically were indistinguishable from the ones observed in the kerosene + fertilizer enclosures.

\section{Discussion}

The 94 to $98 \%$ loss of kerosene from the upper $5 \mathrm{~cm}$ layer within 2 days in unfertilized enclosures was evidently a result of physicochemical processes, i.e. a combination of leaching deeper into the sediment and evaporation. The laboratory studies of Jarsjö et al. (1994) indicate an inherent retention capacity of less than $10 \mathrm{mg}$ per g dry sediment in this rather coarse beach sediment and a shift towards heavier alkanes in the residual fraction (data not shown) indicated a substantial loss also from evaporation. The residual fraction, seemingly recalcitrant to both evaporation and further leaching, was in the range 0.6-1.2 mg per g dry sediment.

Concomitant addition of the Inipol bioremediation agent enhanced retention of the kerosene in the surface layer. The higher hydrocarbon concentration persisted throughout the experimental period in the 2003 experiment, while the residual levels in fertilizer-amended and un-amended enclosures merged after about one month in 2002. This difference suggested an impact of the replacement of the well-established Inipol EAP 22 product in 2002 with Inipol ${ }^{+}$in 2003. Basically, the relative content of the cosurfactant 2-butoxyethanol had been increased relative to the other ingredients to obtain a formulation that worked more efficiently than EAP 22 at low environmental temperatures (F. Périé, personal communication). 
The study confirmed the presence of a significant indigenous population of hydrocarbon degraders, also in remote polar beach sediments supposedly little affected by human activities (Swannell et al., 1995; Delille and Delille, 2000). Addition of the kerosene mixture caused rapid and lasting 1-2 orders of magnitude increases in DC, making hydrocarbon degraders a predominant element of the cultivable bacteria. A highly similar response has previously been observed in sub-Antarctic intertidal sediments (Delille and Delille, 2000). The attained DC levels of $10^{5}-10^{6}$ per $\mathrm{g}$ dry sediment were in the same range as reported for unfertilized plots of comparable field experiments (Delille and Delille, 2000; Delille et al., 2002), however generally lower than what has been observe $\mathrm{d}$ in laboratory and microcosm simulations of intertidal-zone biodegradation (Swannell et al., 1995; Santas and Santas, 2000; Oh et al., 2001). Even after growth stimulation, hydrocarbon degraders constituted just $1-2 \%$ of total epifluorescent counts in the present study. There is ample evidence that substantial fractions of fluorescently labelled bacteria from natural marine environments are inactive or even dead (Lebaron et al., 2001; Luna et al., 2002). Consequently, the contribution by the hydrocarbon degraders to the actively metabolizing subset of microbes may have been substantially higher. On the other hand, the observation that total counts were basically unaffected by kerosene -alone addition both years, pointed to a modest impact on the overall biomass. Thus, the microbial growth seemed severely restricted by the availability of inorganic nutrients. Additionally, loose attachment of the hydrocarbondegraders to the substrate may have resulted in repeated reductions in numbers by flushing out of the surface layer during tidal cycles. The low impact of the hydrocarbondegrading flora was also manifested by the striking stability of the residual kerosene fraction after the initial, supposedly abiotic reduction. In 2002, this stability was 
complete from two weeks on, while a minor reduction was observed during the last month of the 2003 experimental period.

Addition of Inipol EAP 22 did not lead to stimulation in hydrocarbon-degrader counts beyond that of kerosene alone in the 2002 experiment. This contrasts previous studies, where experimental units amended by the product typically have reached 1-2 orders of magnitude higher viable counts than un-fertilized controls (Swannell et al., 1995; Choi et al., 2002; Delille et al., 2002). Seemingly, insufficient quantities of the bioremediation agent resisted drainage out of the upper layer by the tidal flushings to make a difference with respect to microbial growth. Inipol EAP 22's susceptibility to leaching from irrigated sediments has been documented in other studies $\mathrm{Xu}$ and Obbard, 2003). As experimental conditions - temperature regime included - were virtually identical the two years, the distinctly stronger growth stimulation by the Inipol ${ }^{+}$applied in 2003 seemed ascribable to the above-mentioned adjustment in the recipe of the product. Most likely, more of the easily accessible organic nutrients were retained in the surface layer.

Both years the growth stimulation in enclosures added just the fertilizer, was basically identical with what was observed in enclosures added Inipol and kerosene. The 2003 experiment, in particular, suggested that the numerical dynamics of the hydrocarbon-degrading community was distinctly more impacted by the bioremediation agent than by the hydrocarbons per se. One claimed effect of the Inipol products is to initiate an early start of bacterial growth, implicitly of strains with the capacity to catabolize hydrocarbons. This characteristic has primarily been attributed to the presence of about 25\% oleic acid (Ladousse and Tramier, 1991). As mentioned, the benefit of this growth boost for subsequent biodegradation has been questioned (Rivet et al., 1993; Swannell et al., 1995; Pelletier et al., 2004). From the 2003 results of the present study, 
even the ability of the Inipol-induced flora to sustain on the hydrocarbons when more readily degradable $\mathrm{C}$ sources are depleted seems limited. The rapid alkane-degrader proliferations observed after each Inipol ${ }^{+}$addition were equally transient both if the product was added as kerosene supplement or if it was added to the enclosures alone.

Decline over time in the quantitative ratios between the isoprenoid hydrocarbons pristane and phytane and the respective nalkanes heptadecane and octadecane has a long record as indicators of biodgradation in oil (Blumer and Sass, 1972), and the general notion that reductions in these ratios are true reflections of biodegradation still prevails. However, there have also been repeated warnings that quantitative conclusions, at least should be drawn with caution. Both bacterial isolates and consortia have been shown to catabolize the highly branched isoprenoid chains, although mostly at lower rates than straight-chain alkanes (Jobson et al., 1972; Oudot et al., 1998; Garrett et al., 2003; Xu et al., 2003).

When the ratios between presumed biodegradable and recalcitrant molecules are used as indicator of biodegradation, the possibility of abiotically induced ratio change is implicitly disregarded. To our knowledge, the validity of this premise has not been thoroughly re-examined in available literature. From the present study, however, it seems questionable with respect to the heptadecane / pristane pair. Both years the ratio dropped by $20 \%$ of its original value within the first 5 days in Inipol-amended enclosures. These periods were too short in time and alkane-degrader loads were too modest to make biodegradation a plausible explanation. As corresponding developments were not observed in the kerosene-only enclosures, this immediate reduction seemed caused by interaction between the hydrocarbons and the bioremediation agent. Furthermore, the removal rates of the n-alkanes relative to pristane in the subsequent weeks were sensitive to carbon chain length in a manner that seemed incompatible with microbial degradation 
and the heptadecane and pristane retentions did not coincide. Rather, the removal of the straight-chain hydrocarbon proceeded somewhat slower.

In the light of the above-mentioned, putatively non-biotic influences on the $\mathrm{C}_{17}$ / pristane ratio, the steady decline in the 2003 kerosene + Inipol enclosures throughout the experimental period suggested some contribution by biodegradation to the overall hydrocarbon removal. The stronger stimulation in alkane-degrader counts, with peak MPN figures exceeding $10^{8}$ per g dry sediment, pointed in the same direction. The minimum estimate of $17 \%$ biodegradative contribution to the overall removal of residual hydrocarbons is, however, a modest figure compared with previous observations in intertidal sediments (Swannell et al., 1995; Wright et al., 1997; Delille et al., 2002).

\section{Conclusions}

The present study addressed the fate of a light fuel oil (kerosene) spill in high-arctic intertidal-zone sediment and the biodegradative response by the inherent microbial community. The major findings were as follows:

(1) In the upper $5 \mathrm{~cm}$ layer, a residual fraction in the range of $0.6-1.2 \mathrm{mg}$ per $\mathrm{g}$ dry sediment seemed recalcitrant to abiotic removal processes throughout experimental periods of nearly 80 days.

(2) Concomitant addition of an oleophilic fertilizer / bioremediation agent slowed the immediate abiotic removal, leaving substantially higher concentrations of the kerosene in the upper layer for weeks or months.

(3) In fertilizer-amended experimental enclosures, the dynamics in numbers of hydrocarbon-degrading cells seemed primarily impacted by the fertilizer; the 
dynamics in control enclosures with fertilizer only was indistinguishable from what was observed with both kerosene and fertilizer added.

(4) Use of the ratio between heptadecane and pristane as biodegradation indicator was obscured by evidently physicochemical differences in removal rates.

However, it may be concluded that biodegradation was negligible in un-fertilized experimental enclosures. Fertilization gave mixed results, as the established commercial variant of the employed bioremediation agent caused no observable biodegradation, while a minimum $17 \%$ contribution by microorganisms to overall hydrocarbon removal was estimated with a modified, cold-climate adapted variant of the product.

\section{Aknowledgements}

This work has been financed by grants from Total E\&P Norway AS and the Norwegian College of Fishery Science at the University of Troms $\varnothing$. The study was also supported financially by the Roald Amundsen Centre for Arctic Research and the Kellfrid and Helge Jacobsen Foundation of the University of Troms $\varnothing$. Laboratory facilities during fieldwork were provided by the University Centre in Svalbard. The Inipol bioremediation products were kindly provided by CECA SA, France. 


\section{References}

Anders on, O.R., Gorrell, T., Bergen, A., Kruzansky, R., Levandoswsky, M. 2001. Naked amoebas and bacteria in an oil-impacted salt marsh community. Microbial Ecology 42, 474-481.

Aspila, K.I., Agemian, H., Chau, A.S.Y. 1976. Semiautomated method for determination of inorganic, organic and total phosphate in sediments. Analyst 101, 187-197.

Atlas, R.M. 1981. Microbial degradation of petroleum hydrocarbons: an environmental perspective. Microbiological Reviews 45, 180-209.

Atlas, R.M., Bartha, R. 1972. Degradation and mineralization of petroleum in sea water: limitation by nitrogen and phosphorous. Biotechnology and Bioengineering 14, 309-318.

Bachoon, D.S., Araujo, R., Molina, M., Hodson, R.E. 2001. Microbial community dynamics and evaluation of bioremediation strategies in oil-impacted salt marsh sediment microcosms. Journal of Industrial Microbiology \& Biotechnology 27, 72-79.

Blumer, M., Sass, J. 1972. Oil pollution: persistence and degradation of spilled fuel oil. Science 176, 1120-1122. 
Braddock, J.F., Ruth, M.L., Catterall, P.H., Walworth, J.L., McC arthy, K.A. 1997. Enhancement and inhibition of microbial activity in hydrocarbon-contaminated arctic soils: implications for nutrient-amended bioremediation. Environmental Science \& Technology 31, 2078-2084.

Bragg, J.R., Prince, R.C., Harner, E.J., Atlas, R.M. 1994. Effectiveness of bioremediation for the Exxon Valdez oil spill. Nature 368, 413-418.

Brown, E.J., Braddock, J.F. 1990. Sheen Screen, a miniaturized most-probable-number method for enumeration of oil-degrading microorganisms. Applied and Environmental Microbiology 56, 3895-3896.

Choi, S.C., Kwon, K.K., Sohn, J.H., Kim, S.J. 2002. Evaluation of fertilizer additions to stimulate oil biodegradation in sand seashore mesocosms. Journal of Microbiology and Biotechnology 12, 431-436.

Dandie, C.E., Thomas, S.M., McClure, N.C. 2001. Comparison of a range of green fluorescent protein-tagging vectors for monitoring a microbial inoculant in soil. Letters in Applied Microbiology 32, 26-30.

Delille, D., Bassères, A., Dessommes, A., Rosiers, C. 1998. Influence of daylight on potential biodegradation of diesel and crude oil in Antarctic seawater. Marine Environmental Research 45, 249-258.

Delille, D., Delille, B. 2000. Field observations on the variability of crude oil impact on indigenous hydrocarbon-degrading bacteria from sub-Antarctic intertidal sediments. Marine Environmental Research 49, 403-417.

Delille, D., Delille, B., Pelletier, E. 2002. Effectiveness of bioremediation of crude oil contaminated subantarctic intertidal sediment: the microbial response. Microbial Ecology 44, 118-126. 
Fingas, M.F. 2004. Modeling evaporation using models that are not boundary-layer regulated. Journal of Hazardous Materials 107, 27-36.

Garrett, R.M., Rothenburger, S.J., Prince, R.C. 2003. Biodegradation of fuel oil under laboratory and arctic marine conditions. Spill Science \& Technology Bulletin 8, 297-302.

Gibbs, C.F. 1975. Quantitative studies on marine biodegradation of oil. I. Nutrient limitation at 14 degrees C. Proceedings of the Royal Society of London. Series B, Biological Sciences 188, 61-82.

Haines, J.R., Wrenn, B.A., Holder, E.L., Strohmeier, K.L., Herrington, R.T., Venosa, A.D. 1996. Measurement of hydrocarbon-degrading microbial populations by a 96-well pla te most-probable-number procedure. Journal of Industrial Microbiology 16, 36-41.

Jarsjö, J., Destouni, G., Yaron, B. 1994. Retention and volatilization of kerosene: laboratory experiments on glacial and postglacial soils. Journal of Contaminant Hydrology 17, 167-185.

Jarsjö, J., Destouni, G., Yaron, B. 1997. On the relation between viscosity and hydraulic conductivity for volatile organic liquid mixtures in soils. Journal of Contaminant Hydrology 25, 113-127.

Jobson, A., Cook, F.D., Westlake, D.W. 1972. Mic robial utilization of crude oil. Applied Microbiology 23, 1082-1089.

Krajewski, K.P. 1992. Phosphorite-bearing sequence of the Wilhemöya formation in Van Keulenfjorden, Spitsbergen. Studia Geologica Polonica 98, 171-199.

Ladousse, A., Tramier, B. 1991. Results of 12 years of research in spilled oil bioremediation: Inipol EAP 22. In: Proceedings of the $12^{\text {th }}$ International Oil Spill 
Conference, American Petroleum Institute Pub. No. 4529, Washington DC, USA, 577-581.

Leahy, J.G., Colwell, R.R. 1990. Microbial degradation of hydrocarbons in the environment. Microbiological Reviews 54, 305-315.

Lebaron, P., Servais, P., Agogué, H., Courties, C., Joux, F. 2001. Does the high nucleic acid content of individual bacterial cells allow us to discriminate between active cells and inactive cells in aquatic systems? Applied and Environmental Microbiology 67, 1775-1782.

Lee, K. 2000. In situ bioremediation of oiled shoreline environments. Proceedings of the conference Opportunities for Environmental Applications of Marine Biotechnology. National Academy Press, Washington DC, USA.

Luna, G., Manini, E., Danovaro, R. 2002. Large fraction of dead and inactive bacteria in coastal marine sediments: Comparison of protocols for determination and ecological significance. Applied and Environmental Microbiology 68, 3509-3513.

Maki, H., Utsumi, M., Koshikawa, H., Hiwatari, T., Kohata, K., Uchiyama, H., Suzuki, M., Noguchi, T., Yamasaki, T., Furuki, M., Watanabe, M. 2003. Intrinsic biodegradation of heavy oil from Nakhodka and the effect of exogenous fertilization at a coastal area of the Sea of Japan. Water Air and Soil Pollution 145, $123-138$.

Margesin, R., Schinner, F. 1999. Biological decontamination of oil spills in cold environments. Journal of Chemical Technology and Biotechnology 74, 381-389.

Murphy, J., Riley, J. 1962. A modified single solution method for determination of phosphate in natural waters. Analytica Chimica Acta 26, 31-36.

Noble, R.T., Fuhrman, J.A. 1998. Use of SYBR Green I for rapid epifluorescence counts of marine viruses and bacteria. Aquatic Microbial Ecology 14, 113-118. 
Oh, Y., Sim, D.S., Kim, S.J. 2001. Effects of nutrients on crude oil biodegradation in the upper intertidal zone. Marine Pollution Bulletin 42, 1367-1372.

Oudot, J., Merlin, F.X., Pinvidic, P. 1998. Weathering rates of oil components in a bioremediation experiment in estuarine sediments. Marine Environmental Research 45, 113-125.

Pelletier, E., Delille, D., Delille, B. 2004. Crude oil bioremediation in sub-Antarctic intertidal sediments: chemistry and toxicity of oiled residues. Marine Environmental Research 57, 311-327.

Pernthaler, J., Glöckner, F.O., Schönhuber, W., Amann, R. 2001. Fluorescence in situ hybridization (FISH) with rRNA-targeted oligonucleotide probes. Methods in Microbiology 30, 207-226.

Prince, R.C., Bare, R.E., Garrett, R.M., Grossman, M.J., Haith, C.E., Keim, L.G., Lee, K., Holtom, G.J., Lambert, P., Sergy, G.A., Owens, E.H., Guenette, C.C. 2003. Bioremediation of stranded oil on an arctic shoreline. Spill Science \& Technology Bulletin 8, 303-312.

Rivet, L., Mille, G., Basseres, A., Ladousse, A., Gerin, C., Acquaviva, M., Bertrand, J.C. 1993. n-Alkane biodegradation by a marine bacterium in the presence of an oleophilic nutriment. Biotechnology Letters 15, 637-640.

Röling, W.F.M., Milner, M.G., Jones, D.M., Lee, K., Daniel, F., Swannell, R.J.P., Head, I.M. 2002. Robust hydrocarbon degradation and dynamics of bacterial communities during nutrient-enhanced oil spill bioremediation. Applied and Environmental Microbiology 68, 5537-5548.

Santas, R., Santas, P. 2000. Effects of wave action on the bioremediation of crude oil saturated hydrocarbons. Marine Pollution Bulletin 40, 434-439. 
Swannell, R.P.J., Croft, B.C., Grant, A.L., Lee, K. 1995. Evaluation of bioremediation agents in beach microc osms. Spill Science \& Technology Bulletin 2, 151-159.

Swannell, R.P.J., Lee, K., McDonagh, M. 1996. Field evaluations of marine oil spill bioremediation. Microbiological Reviews 60, 342-365.

Swannell, R.P.J., Mitchell, D., Lethbridge, G., Jones, D., Heath, D., Hagley, M., Jones, M., Petch, S., Milne, R., Croxford, R., Lee, K. 1999. A field demonstration of the efficacy of bioremediation to treat oiled shorelines following the Sea Empress incident. Environmental Technology 20, 863-873.

Swannell, R.P.J., Mitc hell, D.J., Waterhouse, J.C., Miskin, I.P., Head, I.M., Petch, S., Jones, D.M., Willis, A., Lee, K., Lepo, J.E. 2000. Impact of bioremediation treatments on the biodegradation of buried oil and predominant bacterial populations. In: Bell, C.R., Brylinski, M., Johnson-Green, P. (Eds), Microbial Biosystems; New frontiers. Proceedings of the 8th International Symposium on Microbial Ecology. Atlantic Canada Society for Microbial Ecology, Halifax, Canada, 759-765.

Venosa, A.D., Suidan, M.T., King, D., Wrenn, B.A. 1997. Use of hopane as a conservative biomarker for monitoring the bioremediation effectiveness of crude oil contaminating a sandy beach. Journal of Industrial Microbiology \& Biotechnology 18, 131-139.

Wright, A.L., Weaver, R.W., Webb, J.W. 1997. Oil bioremediation in salt marsh mesocosms as influenced by $\mathrm{N}$ and $\mathrm{P}$ fertilization, flooding, and season. Water Air and Soil Pollution 95, 179-191.

Xia, W.X., Li, J.C., Zheng, X.L., Bi, X.J., Shao, J.L. 2006. Enhanced biodegradation of diesel oil in seawater supplemented with nutrients. Engineering in Life Sciences 6, 80-85. 
Xu, R., Obbard, J.P. 2003. Effect of nutrient amendments on indigenous hydrocarbon biodegradation in oil-contaminated beach sediments. Journal of Environmental Quality 32, 1234-1243.

Xu, R., Obbard, J.P., Cay, E.T.C. 2003. Optimization of slow-release fertilizer dosage for bioremediation of oil-contaminated beach sediment in a tropical environment. World Journal of Microbiology \& Biotechnology 19, 719-725.

Zhu X., Venosa, A.D., Suidan, M.T. 2004. Literature review on the use of commercial bioremediation agents for cleanup of oil-contaminated estuarine environments. Report No. EPA/600/R-04/075, U.S. Environmental Protection Agency, National Risk Management Research Laboratory, Cincinnati, OH, USA. 


\section{Figure legends}

Figure 1 Placement of the tube enclosures in the intertidal zone.

Figure 2 Sediment surface temperatures within enclosures in the experimental periods 9 July to 26 September (79 days) in 2002 (? ) and 7 July to 23 September (78 days) in 2003 (?).

Figure 3 Total residual extractable hydrocarbons in the enclosures throughout the experimental periods 9 July to 26 September in 2002 (A) and 7 July to 23 September in 2003 (B); (?), kerosene mixture added alone, ( (1 ), concomitant addition of Inipol, with re-addition at day 43 in 2003 (arrow). Error bars represent standard deviation between triplicate enclosures.

Figure 4 Development in the heptadecane / pristane ratios throughout the experimental periods 9 July to 26 September in 2002 (A) and 7 July to 23 September in 2003 (B). The values in the original kerosene mixture (day 0) are scaled to 1.0; (?), kerosene-only enclosures; ( (1 ), kerosene + Inipol enclosures. Error bars represent standard deviations between triplicate enclosures. 
Figure 5 Ratios between individual n-alkanes and pristane in kerosene-only enclosures of the 2003 experiment. The values in the original kerosene mixture were scaled to 1.0; white column, 10 days; light grey column, 24 days; dark grey column, 43 days. Error bars represent standard deviations between triplicate enclosures.

Figure 6 Microbial enumerations by epifluorescent microscopy counts (?), viable heterotrophic plate counts (i ) and viable alkane-degrader MPN counts (?). Figures A-D give the 2002 data (9 July to 12 September) and figures E-H the 2003 data (7 July to 23 September); A and E, control enclosures (no additions); $\mathrm{B}$ and $\mathrm{F}$, enclosures added kerosene alone; $\mathrm{C}$ and $\mathrm{G}$, control enclosures (Inipol alone); D and H, enclosures added kerosene + Inipol. Error bars represent standard deviations between triplicate enclosures; if non-detectable, the error bars are shielded by the point markers. Arrows indicate Inipol re-addition. 


\section{ACCEPTED MANUSCRIPT}

Fig.1

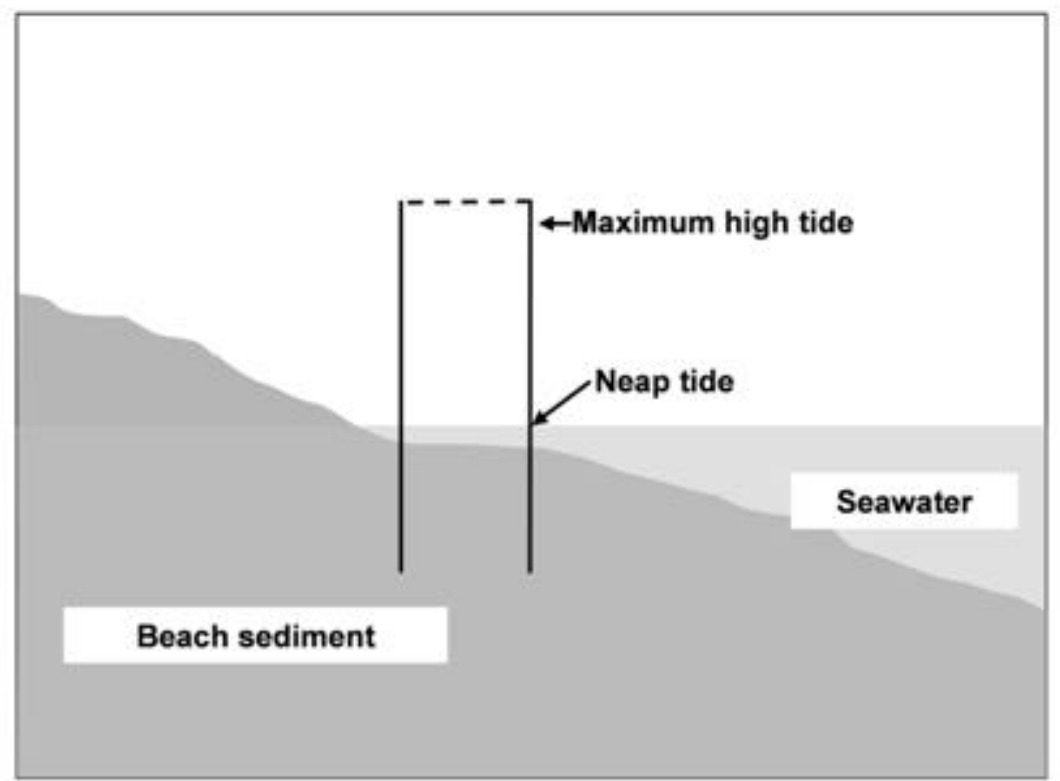


Fig. 2

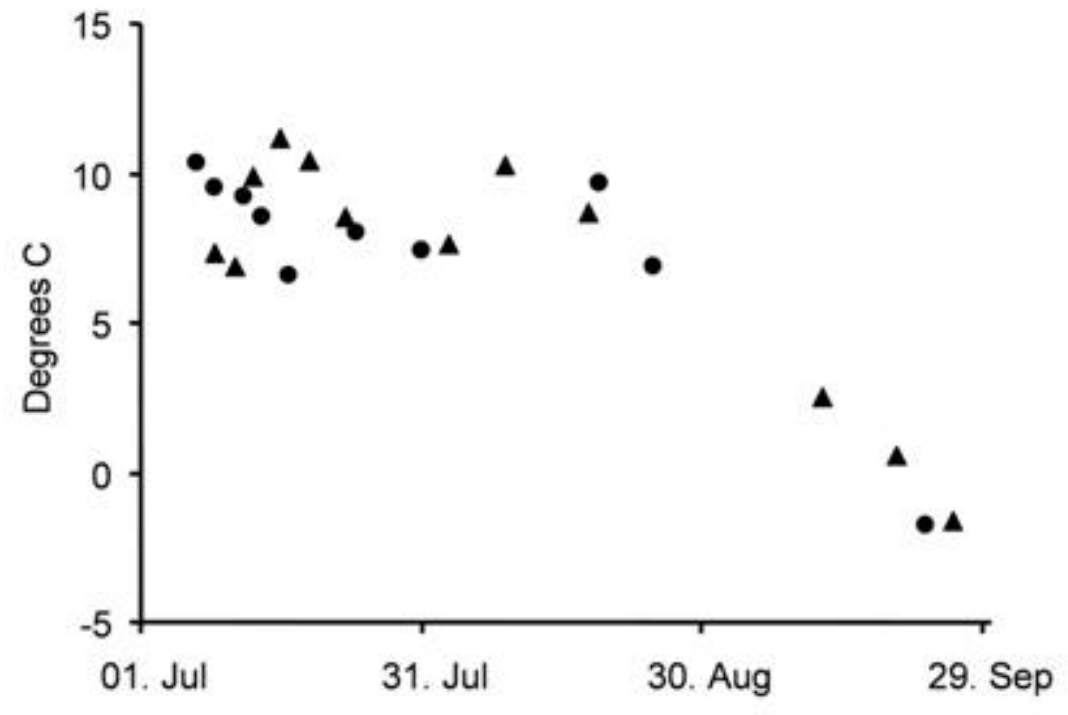




\section{ACCEPTED MANUSCRIPT}

Fig. 3

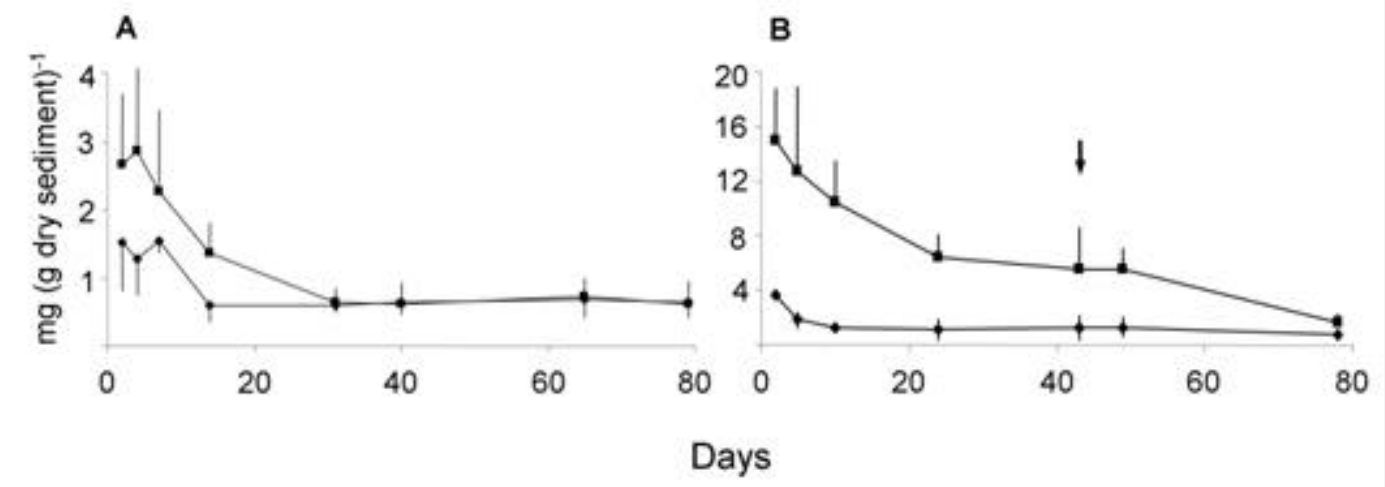




\section{ACCEPTED MANUSCRIPT}

Fig.4

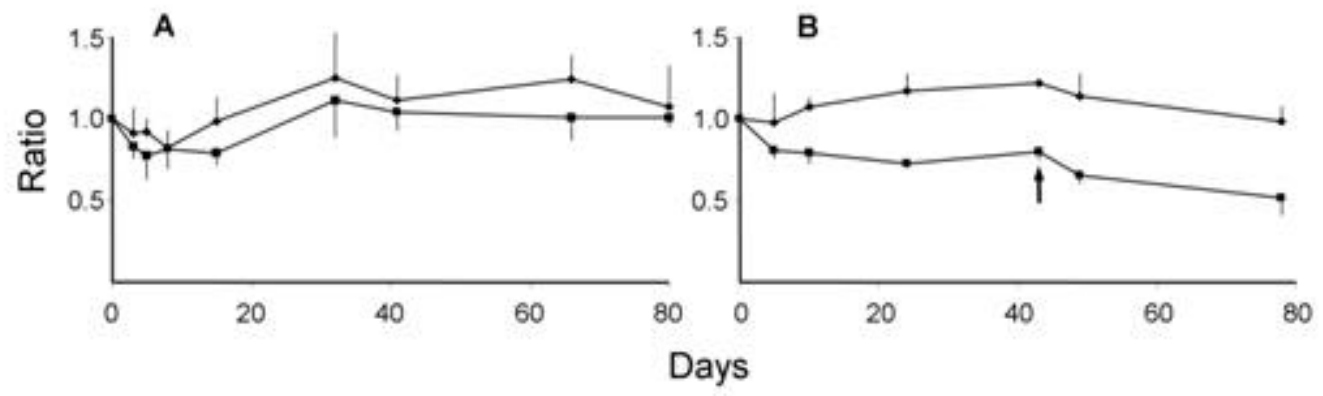


Fig.5

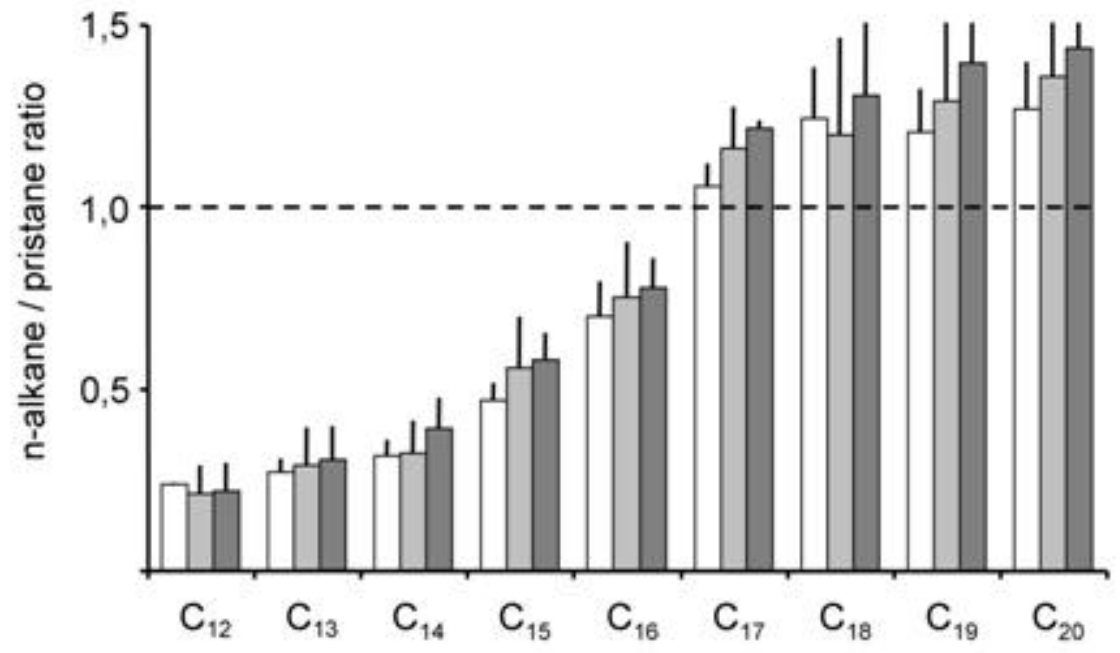




\section{ACCEPTED MANUSCRIPT}

Fig.6

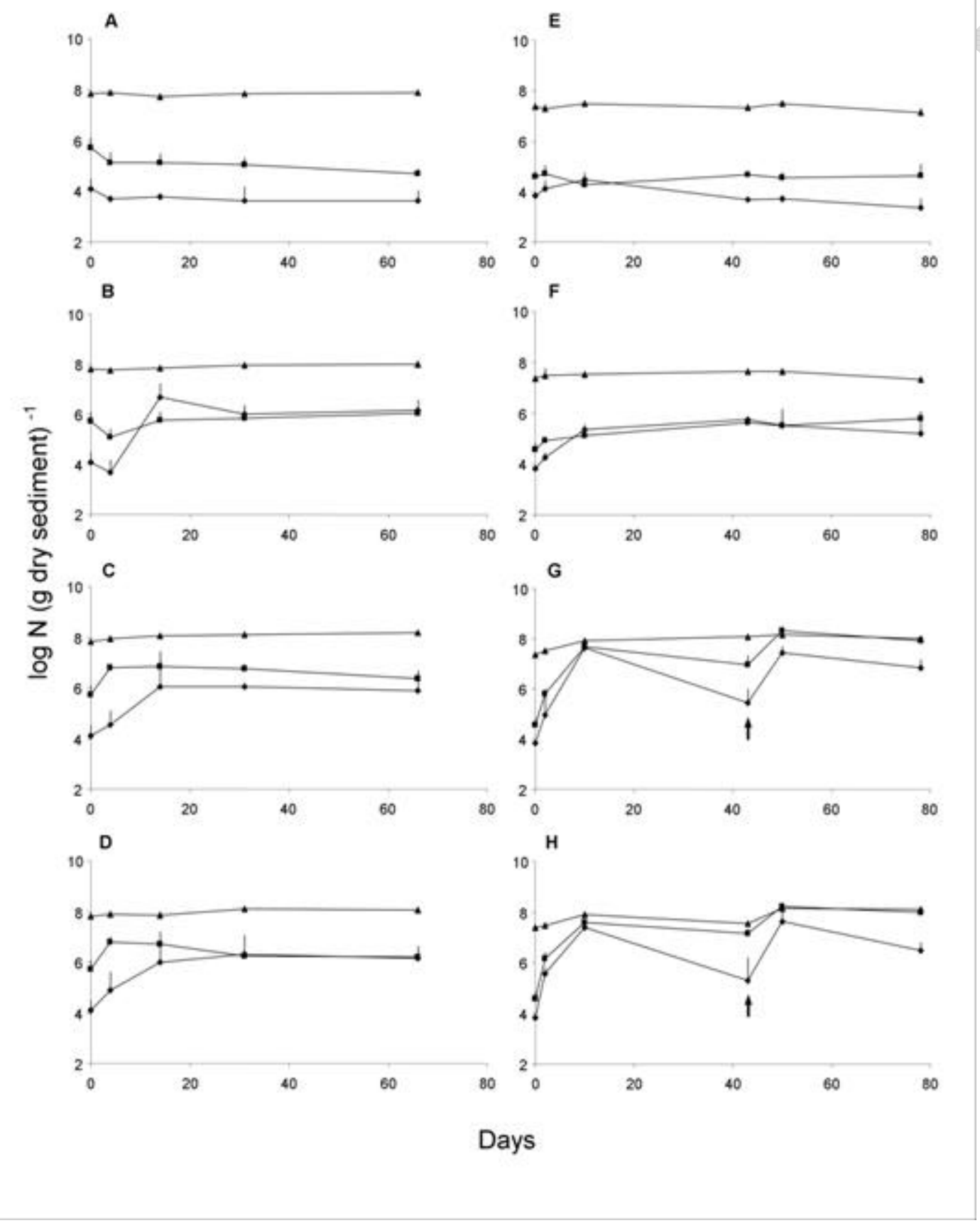


Table 1. Sediment grain size distribution and classification (according to the Wentworth scale) of three individual samples distributed throughout the experimental field.

\begin{tabular}{|c|c|c|}
\hline Classification & $\begin{array}{l}\text { Particle size } \\
\qquad(\mathrm{mm})\end{array}$ & $\begin{array}{l}\% \text { of dry sediment } \\
\text { (S.D) }\end{array}$ \\
\hline Medium gravel & $8-16$ & $6.3(4.9)$ \\
\hline Fine gravel & $4-8$ & $31.3(6.0)$ \\
\hline Very fine gravel & $2-4$ & $17.9(2.6)$ \\
\hline Very coarse sand & $1-2$ & $11.9(3.0)$ \\
\hline Coarse sand & $0.5-1.0$ & $14.8(1.1)$ \\
\hline Medium sand & $0.25-0.50$ & $13.7(4.0)$ \\
\hline Very fine sand & $0.063-0.125$ & $0.3(0.0)$ \\
\hline
\end{tabular}

